\title{
NARRATIVE MODELS IN TOLKIEN'S STORIES OF MIDDLE-EARTH
}

Jaume Albero Poveda

University of Valladolid

\begin{abstract}
In The Lord of the Rings (1954), there is an attempt to unite the two worlds which captivated Tolkien's imagination: the fairy tale world of children's stories which he was drawn to as a child, and the sagas and medieval myths that were the subject of his study and teaching at university. The hobbits are where these two narrative universes meet. In The Lord of the Rings, these two worlds, being difficult to reconcile, collide. On the one hand, we have the hobbits, those everymen with whom the reader can identify easily. They are characters created in The Hobbit (1937) that have a narrative world of their own, as in fairytales, and that are generated with a low mimetic mode. On the other hand, we have the chivalric heroes with a great literary tradition, who belong to the high mimetic mode. Tolkien's fiction is less successful in those episodes in which the hobbits are absent.
\end{abstract}

In this article we shall deal with several formal aspects that will help us to understand J.R.R. Tolkien's writing method. The themes we shall tackle revolve around two cores: the rhetoric of children's literature and fairy tales, used in The Hobbit (1937), and the rhetoric of the matter of Britain, used in The Lord of the Rings (1954). As we are going to explain, Tolkien's fiction is built on the foundations of highly stereotyped and traditional narrative forms, far removed from the literary movements of the twentieth century that searched for personal and innovative fantasies.

\section{THE HOBBIT AND THE RHETORIC OF CHILDREN'S STORIES AND FAIRY TALES}

It seems that, in spite of the illusion of progress, human beings have undergone little inward change. Because of this, present-day readers are still fascinated by the 
stories and narrative motifs that our ancestors created and dispersed. So, the success of books such as Harry Potter, Philip Pullman's trilogy His Dark Materials, and also J.R.R. Tolkien's fantasy of Middle-earth, which captivate the imagination of children and teenagers, owes much to the motifs and elements that have characterized literature across the ages.

The Hobbit is a story Tolkien wrote to tell to his sons at night. When he began writing The Lord of the Rings, his sons were grown up and did no longer want bedtime stories. We agree with Humphrey Carpenter (1977: 200) on the idea that The Hobbit is a children's story, although it has been integrated into a mythology intended for a more adult reader and was written in a more serious tone. The author's original idea when writing the story of Bilbo was for it to be entertaining and amusing for his first audience, his sons. This work does not aspire to achieve the emotional and moral intensity of The Lord of the Rings. The title of the book The Hobbit, or, There and Back Again declares an uninhibited narrative tone. The literary style is indeed very relaxed and the work has a great structural simplicity. Only in the battle of the Five Armies episode do the details of the troops' movement take on the sophistication of modern warfare and the devotion of the participants reaches an epic height. Tolkien's short fiction has maintained the light style characteristic of The Hobbit.

The narrator of Bilbo's story is omniscient, frequently discusses the events described and constantly speaks to the reader as if to a child. As early as the first paragraphs we read: "He may have lost the neighbours' respect, but he gained -well, you will see whether he gained anything in the end" $(\mathrm{H}, 16) .{ }^{1}$ The narrator's knowledge about the elements of the story is superior to that of the characters. In this way, when Bilbo finds the Ring, the narrator comments: "It was a turning point in his career, but he did not know it" (H, 76). Or we can also read "Now, if you wish, like the dwarves, to hear news of Smaug, you must go back again to the evening when he smashed the door and flew off in rage, two days before" (H, 234). The narrator is aware of the reader's cognitive universe. Therefore, he can predict the reader's reactions: "The mother of our particular Hobbit -what is a Hobbit? I suppose Hobbits need some description nowadays" $(\mathrm{H}, 16)$. When he thinks there is enough information to follow the recounted events, he abandons description of the hobbits: "Now you know enough to go on with" $(H, 16)$. Sometimes he deliberately conceals pieces of information in order to generate interest: "Gandalf! If you had heard only a quarter of what I have heard about him, and I have only

1. The title of Tolkien's works will be abbreviated as follows: The Hobbit $(\mathrm{H})$, The Fellowship of the Ring (I), The Two Towers (II), The Return of the King (III), and The Silmarillion (S). 
heard very little of all there is to hear, you would be prepared for any sort of remarkable tale" $(\mathrm{H}, 17)$. On other occasions, he omits data that the reader already knows: "You are familiar with Thorin's style on important occasions, so I will not give you any more of it, though he went on a good deal longer than this" $(\mathrm{H}, 203)$. The narrator also establishes a direct dialogue with the reader; because of this, he is sometimes mentioned: "There is little or no magic about them, except the ordinary everyday sort which helps them to disappear quietly and quickly when large stupid folk like you and me come blundering along" $(\mathrm{H}, 16)$; or also in "There was a lot here which Smaug did not understand at all (though I expect you do, since you know all about Bilbo's adventures to which he was referring)" (H, 213). He also addresses the reader with a direct, conversational tone: "As I was saying, the mother of this Hobbit" $(\mathrm{H}, 16)$ or "whether you believe it or not" (H, 273). Moreover, he is conscious of the fact that his narration is in a written medium, as the narrator explains, referring to a song by the dwarves: "Then off they went into another song as ridiculous as the one I have written in full" (H, 59). On another occasion, he postpones reporting the adventure: "It was not very long before of his unfortunate friends. It was not very long before he discovered; but that belongs to the next chapter" (H, 166). We can notice the childlike tone of certain expressions: "(If you want to know what cram is, I can only say that I don't know the recipe; but it is biscuitish, keeps good indefinitely, is supposed to be sustaining, and is certainly not entertaining, being in fact very uninteresting except as a chewing exercise. It was made by the Lake-men for long journeys)" (H, 232).

The Hobbit is a well-established book in the tradition of children's narrative, of which the most notable exponents in British letters are Lewis Carroll, Kenneth Grahame, Beatrix Potter and George Macdonald. As Lois R. Kuznets (1981: 150151) has shown, Bilbo's story fits into the rhetorical structure of children's fiction, which combines the following features: an omniscient narrator that comments on events and addresses the reader directly, characters preadolescent children can easily identify with, an emphasis on the relationship between time and narrative development within the framework of a condensed narrative time, and a defined geography in which safe and dangerous spaces are separate. These characteristics are evident to a greater degree in Bilbo's story than in Frodo's. Two features mark the difference between the tones of these novels. As far as the relation between time and narrative development is concerned, the action in The Hobbit covers approximately one year and emphasizes the changes in season. The characters' movements in space correspond to the seasonal changes.

Bilbo fits into the rhetoric of children's fantasy more than Frodo does because the former is a character that does not evolve at all throughout the story, and the 
events in which he takes part seem not to affect him. The hobbits and the dwarves, because of their height, their cheerful personalities and their habits are creatures with which a young reader can easily identify. The hobbit houses, holes hidden in the mountainside, speak very well to the child's inclination to hide in small places. Just like children, hobbits are fond of riddles, puns and lexical creativity that sometimes transgress grammatical norms. They are also curious to hear old tales and stories. Their habits of eating six times a day, of going barefoot, etc. bring them closer to childlike behaviour. The songs the main characters sing in The Hobbit are to a large extent cheerful, insubstantial and suitable for the enjoyment of little ones. In general, these songs intensify the lively tone of the story and show the joyous personalities of the singers, usually hobbits and dwarves. However, the aim of the songs and poems inserted in passages of great dramatic or emotional tension in The Lord of the Rings is to introduce a peaceful moment and to create an aesthetic distance. As in the epic poems sung in the Middle Ages, those who recite the poems and elegiac songs in The Lord of the Rings are creators of honour. In these works, life and literature merge.

Tolkien avoids sexual content in his novels of Middle-earth. This is a typical feature of stories traditionally addressed to children. The only explicit allusion to sexuality is Gríma Wormtongue's desire for Éowyn, promised by Saruman to this villain as a reward for joining the evil forces. The word sex and its derivatives do not appear in the fiction of Middle-earth, that is, the fantasies from The Hobbit, The Silmarillion and The Unfinished Tales of Middle-earth and Numenor to The Lord of the Rings. It seems as if the term is avoided even when speaking of reproduction. In this way, we can read that orcs "multiplied after the manner of the Children of Ilúvatar" (S, 50). The children of Ilúvatar are elves and men, and both of them reproduce sexually.

One of the thematic innovations in children's literature in recent decades is the game of transgression of social norms. Prior to the first half of the twentieth century, books for children and young people privileged moral adaptation in their writing. As Teresa Colomer (1998: 203) has pointed out, this contravention of the rules of behaviour and order is due to a relaxation in the social conception of these rules and to a wish on the part of children's narratives to incorporate the reflection of children's antisocial feelings. This attitude has been promoted, in part, by psychoanalytical trends, which assert that people should not deny their own fantasies and urges. The crisis of a unique moral model has favoured a sort of children's literature that emphasizes the individual right to freedom and pleasure against subjection to hierarchy and the observance of preestablished norms. In this way, the model of correct behaviour has expanded, and the characters in children's 
fiction can be unrulier, greedier or lazier than what social norms consider proper conduct. The Hobbit can be inscribed in this new tradition of books that contain a remarkable permissiveness in the amount of acceptable uproar and violence in characters' behaviour without any of it being censored. The young reader of The Hobbit old enough to internalize social norms will experience a therapeutical delectation when he notices that the characters do not respect them.

The initial chapter of The Lord of the Rings, "A Long Expected Party," opens the novel in a comedic way, following the model of The Hobbit. This is a hinge chapter between the narrative tone of Bilbo's story and Frodo's. However, in this last story humour loses most of its childishness. The fun scenes have more of a touch of sarcasm about them. By way of example, we can remember the labels tied to the parcels containing Bilbo's gifts to his guests. At the same time as the hobbit gives the presents to his friends and relatives, he censures some of their bad behaviour.

Superstitions and folk proverbs are a way of linking the fantastical world of The Hobbit with a reality familiar to children. In this way, for instance, the dwarves ask Gandalf to look for a fourteenth member for the thirteen dwarves' expedition, because thirteen is considered to bring bad luck in the Judaeo-Christian religious tradition. We must remember that eleven apostles sit with Jesus in the Last Supper. They made a group of twelve people, and Judas, who betrayed Jesus Christ, was the thirteenth fellow dinner. As far as proverbs that children can understand are concerned, we can quote several: "third time pays for all" (H, 203; H, 223), "While there's life there's hope" $(\mathrm{H}, 223)$ and "out of the frying-pan into the fire" $(\mathrm{H}, 96$; $\mathrm{H}, 103)$.

The Hobbit is a story that fits the heroic schema emblematic of the folktale well, since in this novel Bilbo and his companions are trying to advance their interests. The heroes' motivation in Frodo's story has instead the more transcendental significance of a struggle between good and evil in which the hobbit and company establish themselves as the saviours of the free peoples of Middle-earth.

Folktales are often written according to a ternary model, so that an episode, scene or element appears three times. This tripartite distribution of material possibly contributed to the stability of these stories through the centuries, since it facilitates their memorization and increases their rhythm and artistic value. Tolkien parodies this reiterative, typical folktale style in two episodes of The Hobbit. The first is when the thirteen dwarves who invite themselves to supper at Bilbo's smial appear consecutively. The second one occurs when the Ring fellowship turns up before Beorn two by two.

In The Hobbit Tolkien links the world of childhood to the world of folktales, yielding to a widespread opinion -even in academic contexts- that our author 
always fought, particularly in his essay "On Fairy Stories" (1947), according to which fairytales are stories addressed fundamentally to a child audience. Nevertheless, in spite of concessions to younger readers in terms of style, The Hobbit is not a novel conceived for children, because of its absence of female characters and its educational values. As Tolkien stated in a letter edited by Humphrey Carpenter (1981: 200), it was not his intention to write a book for young people either, as he himself emphatically asserted: "I am not interested in the 'child' as such, modern or otherwise, and certainly have no intention of meeting him/her half way, or a quarter of the way".

In The Hobbit we notice the tendency to anthropomorphize animals, a strategy often used in folktales and in stories created for young readers. The primary examples of this personification of animals are: Beorn, the man who turns into a bear at night, the eagles that help the heroes and the dragon Smaug, who talks to Bilbo and reveals completely human pastimes and vices in the dialogue. The personification of animals makes children feel closer to them and they can also identify with them and project their most primary and socially unacceptable instincts onto them.

One motif reminiscent of works belonging to children's fiction is the treasure map the dwarf Thorin receives from his dying father. The motif of the child who obtains a map from a man on his deathbed appears in Treasure Island, when Captain Bill gives young Jim the map of the isle where the pirates' treasure is hidden (cap. II). As Tolkien (1997: 134) wrote in his essay on fairytales, he read this work by Robert Louis Stevenson when he was a child.

In The Hobbit, for characters who would play the heroes, Tolkien primarily chose to stay close to the average human mentality by choosing creatures like the hobbits and the dwarves. But in Frodo's story, he introduced heroes of greater social status with a lofty value system, such as elves and men, who in the first story play a more secondary role and have a very trivial narrative treatment. In this sense, it should be remembered that when Bilbo and his fellow travellers arrive in Rivendell they find a group of elves singing a comical song, composed of jocular verses. In The Hobbit the elves can be, in addition, easily deceived. When the dwarves are taken prisoner, Bilbo manages to rescue them by taking advantage of a night in which the watchmen are drunk and sleeping, and he hides them in empty barrels he sends down the river all the way to the Lake-town. In The Lord of the Rings, in contrast, this race is extolled, and as early as the first paragraphs, we notice that it is venerated by a character as straightforward as Sam Gamgee. On the other hand, men are not as trivialized in The Hobbit as are elves, but we cannot find characters among them with Aragorn's mythical stature. 
The character of Tom Bombadil that appears in the first paragraphs of The Fellowship of the Ring (cap. VI) is an example of how Frodo's story is written according to the rhetoric of children's literature. Tom Bombadil was originally a doll belonging to Michael, one of the author's sons. He had a hat with a feather as does the eponymous character in The Lord of the Rings. However, Michael disliked this doll and one day threw it in the toilet. The doll was rescued and Tolkien made it the protagonist of a poem titled 'The Adventures of Tom Bombadil,' that was published in Oxford Magazine in 1934.

Tom Bombadil is a little taller than the hobbits and has red cheeks. He wears a blue jacket, yellow boots and a hat with a blue feather. This character walks around the Old Forest jumping and happily singing nonsense songs. When he laughs he passes it on to the people around him. One day the hobbits stay at his house which is situated on a hillock of the river Withywindle. His partner is Goldberry, a kind of water sprite.

Tom Bombadil is a character typical of the mythicizing of children's innocence that took place in children's literature written in Great Britain at the end of the nineteenth century. He is a character cut off from the reality of Middle-earth. The Ring does not have any influence in his territory. The wise men refuse to have him as an ally against Sauron because, if he were asked to hold the Ring, he would probably end up throwing it away. Nobody in this earth knows who he is, and when asked about his identity, he answers in an equivocal and ambiguous way. Tolkien stated in a letter edited by Carpenter (1981: 174) that "in a mythical Age there must be some enigmas, as there always are. Tom Bombadil is one (intentionally)".

The Hobbit has a simple narrative structure, without major digressions from the main storyline. In spite of the fact that the narrator provides the reader with some information about the context, the story has an acceptable narrative economy. In the plot structure, there is a sense of progression in the level of difficulty of the obstacles Bilbo has to overcome. Three trolls capture him and the dwarves, but they manage to escape easily. These creatures are slow-witted and argue about how they should cook their prisoners. Gandalf convinces them to go on talking until sunrise. When the light of daybreak appears they become petrified and Bilbo and his fellow travellers are able to escape. Two and a half months later, the group is captured by the goblins. When they are about to be killed Gandalf causes a great explosion that allows them to run away. Immediately afterwards, Bilbo runs into Gollum, a creature who eats every type of meat. Thanks to the Ring of invisibility he found in the underground lake, Bilbo is able to avoid Gollum. Later, Bilbo and his companions escape from the wargs pursuing them, thanks to the help from the eagle Gwaihir. A few days later, giant spiders capture the dwarves but Bilbo frees 
them with the same Ring. The hobbit rescues the dwarves again when the elves lock them in cells. Nevertheless, all these episodes relate unimportant and unconnected incidents if we compare them to the battle against the dragon Smaug, an episode that brings the narrative action together. In this battle, five armies fight and there are many casualties. Through this whole storyline, we notice that Bilbo's enemies and the dwarves achieve greater importance as the action moves forward and reaches the crucial moment in the battle of the Five Armies.

People who reread The Hobbit after reading The Lord of the Rings and The Silmarillion will find that the landscape where hobbits and dwarves cheerfully wander about is more sinister than a first reading reveals. They realize that Sauron had settled in Mordor in the days when Bilbo was looking for the treasure of the dragon Smaug, although neither the villain nor his territory are cited. The Shire and the free peoples of Middle-earth were already threatened when Bilbo was peacefully smoking his pipe in his smial.

\section{THE LORD OF THE RINGS AND THE RHETORIC OF THE MATTER OF BRITAIN}

After the first editions of The Hobbit had sold out and the New York Herald Tribune had awarded its author the prize for the best children's book of the season, the book's editor, Stanley Unwin, wrote to Tolkien asking him to write a sequel to the hobbit story. At first, Tolkien asserted that he had already said everything about the hobbits, ${ }^{2}$ but later committed himself to continue their story, informing Stanley Unwin of the difficulty of eliminating the imagery he had poured into a more mythical story like The Silmarillion.

Some months later, in a letter to C.A. Furth of Allen \& Unwin edited by Carpenter (1981: 34), Tolkien announced that the sequel to The Hobbit had strayed from its model: "I have begun again on the sequel to the 'Hobbit' -The Lord of the Rings. It is now flowing along, and getting quite out of hand. I have reached about Chapter VII and progresses towards quite unforeseen goals". In a latter letter also published by Carpenter (1981: 41) he explains the meaning of the expression 'out of hand': "I really meant it was running its course, and forgetting 'children,' and was becoming more terrifying than the Hobbit. It may prove quite unsuitable. It is more 'adult'". In short, The Lord of the Rings is not a novel that belongs in the children's genre like its predecessor, but a work of epic romance.

2. "I cannot think of anything more to say about Hobbits. Mr. Baggins seems to have exhibited so fully both the Took and the Baggins side of their nature" (Carpenter 1981: 24). 
Perhaps because of the inertia created by the popularity of The Hobbit among young people, the novel that followed was very much read by young children. Tolkien was aware of the fact that, unlike its predecessor, the story of Frodo was a work of a mythological vocation addressed to an adult public. In a letter from our author to his aunt Jane Nave included in Carpenter's corpus (1981: 249), he affirms this: "I find that many children become interested, even engrossed, in The Lord of the Rings, from about 10 onwards. I think it rather a pity, really".

In The Lord of the Rings Tolkien uses a stilus ornatus, full of epithets, superlatives, metaphors and descriptive passages. The style of The Hobbit comes closer to the concise mode of narration typical of the folktale. One of the reasons for the inharmonious collision of hobbit world with the chivalric one is the fact that Tolkien did not prepare an overall design for The Lord of the Rings. The author himself revealed that he did not work with a prefabricated plan for the novel's composition: "This tale grew in the telling, until it became a history of the Great War of the Ring" (I, 8). In the beginning, he wanted to set up a general outline, but, as he explained to Daniel Grotta (1976: 107), "all the things I tried to write ahead of time just to direct myself proved to be no good when I got there. The story was written backwards as well as forward".

In the fantasy of the Ring the comical episodes, typical of the picaresque novel, such as Bilbo's riddle game with Gollum or Frodo's disappearance at his birthday party, alternate with episodes of deep epic emotion, as in the burials of Boromir and the king Théoden. In this novel there coexist songs and poems with a comical tone, like the one Frodo sang in the Prancing Pony with others more significant, as in the poem Aragorn recited on the occasion of the death of King Théoden. Together with names that use the pronunciation of old languages, which bear the weight of a linguistic and literary tradition, such as Eärendil, Anarion, Thrór or Lúthien in the stories of the Ring, there are other names with childlike phonetics like, for instance, Ori, Dori, Nori, Bifur, Bofur, Bombur, Bilbo, Poppy, Dudo or Balbo. The surname Baggins has a funny origin, since at the beginning of the twentieth century baggings was an argot form of snack, which turns out to be a strange appellative when applied to characters who eat six meals a day.

The initial tone of The Lord of the Rings is the same as in The Hobbit. In fact, both stories begin with a celebration. The Ring serves as narrative element to bind the two stories. Moreover, our author created another hobbit, Frodo, to play the lead in the new novel. However, as the writing of the work progressed, Tolkien had some troubles in making the most of the literary world of the hobbits. Little by little, he moved away from a funny tone of the story of Bilbo. His style took on a more serious and solemn tone. The name of Frodo, replacing the original, Bingo, 
for the hero of this new story, shows its more transcendental tone. In fact, Tolkien was more interested in mythical narration, in lofty style, like the unfinished The Silmarillion, than in the story of the hobbits.

The Lord of the Rings is a work with several narrative tones. It begins with a chapter that has a conversational and uninhibited tone. It seems clear that the author had young readers in mind for the first chapter of the work. This is why he invents comical terms such as "eleventy-one" (I, 44) to refer to Bilbo's $111^{\text {th }}$ birthday, or "tweens" (I, 44, 71) to allude to the human period of life from twenty to thirty. This ungrammaticality is a resource sometimes practiced by the narrator of The Hobbit, as when Bilbo, irritated, declares: "Confusticate and bebother these dwarves!" (H, 24). In the first few chapters of the work we can find some of the asides that also characterize the narrative voice of The Hobbit. So we can read: "That very month was September, and as fine as you could ask" (I, 47). The narrator is sometimes unreliable: "A day or two later a rumour (probably started by the knowledgeable Sam)" (I, 47). This lack of certainty in the narrator's statements indicates that he sometimes identifies with the hobbits Bilbo and Frodo. Nevertheless, the narrator is omniscient: "His real business [Gandalf's] was far more difficult and dangerous, but the Shire-folk knew nothing about it" (I, 48). The narrator comments on the characters' actions: "Hobbits give presents to other people on their own birthdays [...] but it was not a bad system" (I, 50-51). As the plot progresses, the narrative voice becomes more neutral and the narrator disappears behind the characters.

The first of the six books that make up Frodo's story, which is included in the volume The Fellowship of the Ring, as we have said before, follows the light and unimportant tone of The Hobbit by force of habit. The "Long expected party" is an amplified version of the comical "unexpected party" of Bilbo's story. In the initial chapters of both stories, Gandalf visits a hobbit to announce that he has to leave the Shire and go away. In the first chapters there are many singing poems that include puns. The episode of the encounter with Tom can be left out, from a narrative point of view, because it does not provide the reader with material on the theme of the journey and it will be forgotten after this first meeting. It is perhaps because of this lack of function that the episode has been cut out of the film version of the novel. The majority of incidents in these first paragraphs of the work can likewise be omitted, because they are worked out in a manner irrelevant to the plot's development. On the second day of their journey, the hobbits see a horseman riding a black horse. However, they are able to hide and the horseman passes them. Then they meet Maggot, a farmer who has three ferocious dogs, who was very kind to the hobbits. An old willow captures Frodo, Merry and Pippin 
under its roots, but Tom Bombadil rescues them, as he does later when they are enchanted in the Barrow-downs. These episodes are separate from the main purpose of the journey and from the villains Sauron and Saruman. In books II and III of The Lord of the Rings, the narration is less episodic, and the different storylines are intertwined and the story becomes more complex. This source of the interconnection is, as Tom Shippey (1992: 143-145) has pointed out, an old pre-novelistic technique, whose major literary achievement is the sequence of prose tales called the Vulgate Cycle. The basic pattern at the core of Frodo's story is separation, chance meetings and adventures, which are regulated by maps and a strict chronology. A book as long as The Lord of the Rings probably required a narrative technique that drew the material together, since it is presented in a slightly scattered way.

These initial episodic incidents and the long stays in Rivendell and Lothlórien break the narrative rhythm and slow down the plot. This is why Frodo states in a dream: "I am too late. All is lost. I tarried on the way" (II, 402). Gandalf also regrets his lack of promptness when he explains, referring to Caras Galadon: "I tarried there in the ageless time of that land where days bring healing not decay" (II, 135). Although from the beginning of The Lord of the Rings the need is stated to destroy the Ring immediately, the plot tension created by means of this method is counteracted by the same development of the story.

In the fantasy of the Ring there are countless characters that appear only once in the three books: Adaldrida Brandybuck, Adalgrim Tuk, Belga Bolger, Belmarie, Brownlock, Elfhild, Éothain, Eradan, Fengel, Ferdibrand Tuk, Freáwine, Rowan and a long list of others. These names do not form a hive of people who interact with one other, but are rather mere references. The same phenomenon occurs with the names of places: Egladil, Entwash Vale, Everholt, the seven rivers of Ossir, Shadowmere, the road of the South, Standelf, etc., which are all mentioned only once. Sometimes it is difficult to distinguish the names we are not familiar with because of their phonetic proximity. We can think, for instance, of Angrenost, Angrim, Angrist, Angrod, Anguirel; Calacirian, Calacirya, Calaquendi, Calembel, Calenardhon, Calenhad, Calimehtar, Calimmacil, Calion, Calmacil, Calmatéma; or also Caradhras, Caranthir, Caras Galadon, Carcharoth, Carchost, Cardolan; etc. The lexical prolixity of the author becomes paroxysm when he assigns several names to the same character. In this way, Sauron has earned nearly thirty synonyms, namely: Sauron the Deceiver, Lord of the Earth, the Enemy, the Master, the Dark Power, the Dark Lord, Lord of Mordor, Dark Lord of Mordor, the Power of the Black Land, the Black Master, the Black One, Lord of Barad-dûr, Lord of the Dark Tower, the Shadow, the Great Eye, the Red Eye, the Eye of Barad-dûr, the Lidless Eye, the Evil 
Eye, the Unnamed, the Nameless, the Nameless One, the Nameless Eye, He, Him, the Lord of the Rings, Lord of the Ring, the Ring Maker and the Black Hand. Aragorn is called at least twelve different names: Elessar, Elfstone, Strider, Telcontar, Isildur's Heir, the Renewer, Longshanks, Wing-foot, etc. The Valar have the following designations: Belain (sing. Balar), the Great Ones, the Mighty, the Powers, the Powers of Arda, the Rulers of Arda, the Powers of the World, the Guardians of the World, the Lords, the Lords of Valinor, the Lords of the West, the Authorities, the Deathless, the Gods and the Enemies beyond the Sea. Ilúvatar, to give one last example, is also known as Eru, Eru Ilúvatar, the One and God. Our author's interest in languages led him to designate the same thing in several ways. Therefore, many towns, characters and places have various names. Sometimes, this verbosity slows down the rhythm of the story.

The practice of mentioning characters with several names is typical of mythical narrations and chivalric literature, where we can find heroic epithets (for example, "El de la barba vellida" or "El que en buena hora cinxó espada," referring to the Cid Campeador). In this way, in the Nordic tradition, Odin is given more than fifty names, some of which refer to events in his adventures.

The abundance of personal and place names in Tolkien's fiction must be placed in the context of his philological vocation, which was often a hindrance rather than an assistance to his novelistic side. He even thought of writing the whole trilogy in Elvish, one of the languages he had invented. It can be said that in Tolkien's fiction the Word comes first and the story follows. The writer states this idea in a similar way when he says in a letter compiled by Carpenter (1981: 219) that "The invention of languages is the foundation. The 'stories' were made rather to provide a world for the languages than the reverse. To me a name comes first and the story follows".

The care taken in the detailed descriptions, the attempt to explain the psychological motifs behind the characters' behaviour, the huge wealth of references that the narrator periodically updates in order to facilitate the reader's understanding, are usages typical of the realistic technique that when applied to a work of romance fantasy such as The Lord of the Rings make it less lively and fresh. A stylistic feature that clutters the prose in Frodo's story and makes it more artificial is the practice of creating proper names by using a capital letter for the first letter of common nouns. In this way, we find place names such as the Sea, the City, the Gate, the Door, the Road, the House or the Darkness. The same thing happens with time references such as the Elder Days, the Wandering Days, the Younger Days, or just the Days; or with names of objects such as the One, the Seven, the Nine, etc. The emotive climate of the story rises considerably when the 
narrator tries to confer a unique nature on so many beings, objects, places and concepts. Many of the sentences and expressions in The Lord of the Rings are saturated with capitals: "The Jewels were coveted by Morgoth the Enemy, who stole them and, after destroying the Trees took them to Middle-earth" (III, 388). Or also: "Samwise the Strong, Hero of the Age" (III, 216) or "O Bilbo the Magnificent" ( $\mathrm{H}, 277)$, expressions that when applied to a member of the childlike race of the hobbits become ridiculous. We also read: "Mordor draws all wicked things, and the Dark Power was bending all its will to gather them there. The Ring of the Enemy would leave its mark, too, leave him open to the summons. And all folk were whispering then of the new Shadow in the South" (I, 91). The abuse of capitalization, instead of creating the illusion of transcendence, makes the style pompous. What is more, the use of archaic forms such as "ye" and "hath" and the inversion of nouns and adjectives clutters some passages in The Lord of the Rings. Nevertheless, the archaic style is not predominant throughout the story, but is used in episodes relating to the world of elves and men -in short, those inspired by epic fantasy (chiefly books II and III).

In the foreword to his mammoth work, The Lord of the Rings, Tolkien asserts that the main flaw of his book is that it is too short (I, 10). The author probably regrets his book's brevity because it is impossible to include his entire narrative universe in just one novel. The Silmarillion is an attempt to complete this literary cosmos. Frodo's story is not a novel characterized by brevity or narrative economy. We have not detected any subject to be developed, but rather, we censure the repetition in the use of some narrative formulas and the functional duplicity of some episodes. Our criticism of the book's excessive length can also be justified by the fact that to fully understand Frodo's story, we have to refer to information external to the main body of the narration. The Lord of the Rings is indeed a sequel to The Hobbit that forms part of the geographical and temporal context developed in The Silmarillion. Moreover, it has been found necessary to amend the narrative part of Frodo's story with a foreword, a prologue and several appendices that reduce the narrative's autonomy. In order to know who the Valar are-quoted several times (II, 341; III, 138; III, 304)- we have to refer to appendix A (III, 390). In a similar way, we can read in this appendix: "the Valar laid down their Guardianship and called upon the One" (III, 392). "The One" is Ilúvatar (God). However, this name does not appear in the body of the story. To know the identity of this character we have to read The Silmarillion, which was published posthumously by one of the sons of the author. The Valar took part in a battle called The Battle of the Valar, which is quoted on just one occasion in Frodo's story (III, 138), but we can only know about it if we read The Silmarillion. 
Tolkien adopted an attitude that was characteristic of nineteenth-century Romantic authors. When confronted with technological progress and the crisis of traditional human values, he decided to focus his attention on the Middle Ages as a source of mythology and higher religious-social morals. The influence of medieval literary references and the use of the medieval period as a source of inspiration means that Richard West was making no exaggeration when he qualified Tolkien (as well as C.S. Lewis and T.H. White) as a "medieval contemporary author" (West 1975: 9-10, 15).

Tolkien found inspiration in the myths and sagas from the past, but never claimed any patent of originality. In this way, he followed the creative tradition of Antoni Gaudi, for whom originality consisted of revisiting origins. It is necessary to diminish the importance of Tolkien's creative capacity, because many small incidents in the novels are chiefly inspired by medieval works. We must remember, for instance, the episode of the Arkenstone, the precious stone that Bilbo steals from the dragon Smaug's treasure. This episode is reminiscent of the cup stolen from the dragon and handed over to the king in Beowulf. The search for literary models turned Tolkien into an artist who recreated more than created; who imitated more than invented. Tolkien reformulated the narrative materials from tradition, although sometimes he did not manage to fully integrate his narrative schemas.

In the Middle Ages Tolkien found a stable period with historical and cultural order. In it, he could take refuge from modern society, which was changing at a breakneck pace. In the study of ancient languages, which, not being alive, do not change, Tolkien found a predictable, coherent world that was subject to known rules. He also felt secure in the literary gatherings of the Inklings, a safe environment with friends who shared his liking for centenary traditions. There are also religious reasons for our writer's interest in the Middle Ages. In this period, religious faith had possibly taken deeper root in people's minds and everyday activities, in their rites and daily tasks, than in the materialistic twentieth century.

The author of the fantasy of Middle-earth consciously distanced himself from the literary trends of his time. His work neither develops nor updates the aesthetic criteria of the writers who immediately preceded him, nor does it follow the main currents of his contemporaries. The most important references our author makes are to medieval works. It is significant, to that effect, that in the foreword as well as in the prologue to The Lord of the Rings Tolkien avoids using the term novel to refer to the work he is introducing. This word began to be used in a generalized way after 1840. Before this date, the designation romance was more typical. So, to refer to The Lord of the Rings Tolkien speaks about tale, book, history, sequel to The Hobbit, story, mythology and legends, but never novel. He never applied this label 
to his literary works in his letters. Besides, in one of them, dated in October 1971, he states that he is not worried about the situation of the English novel because his "work is not a 'novel,' but an 'heroic romance' a much older and quite different variety of literature" (Carpenter 1981: 414). Tolkien also separated voluntarily from the artistic tendencies of his time when he created an imaginative world from medieval elements and to describe it he forced the syntax with the use of archaic inversions in the passages relating to chivalric nobility, particularly in the dialogues ${ }^{3}$.

\section{CONCLUSIONS}

In The Lord of the Rings Tolkien incorporated a chivalric plot with a quest that is typically folkloric in its conventions and characters. As previously stated, this combination is not a seamless one. So, the main plot -the destruction of the Ring- is a derivative of the plot involving the war against Sauron's armies. Characters in The Lord of the Rings are more serious and transcendental than they are in The Hobbit. Frodo's mission is much more important than Bilbo's and involves a greater degree of personal sacrifice. In a parallel process, the narrative form itself becomes more serious. In The Lord of the Rings, the narrator exaggerates his descriptions and he risks making meaningless expressions. The chapters are longer in Frodo's story, and the narrative tension increases; the characters speak with heightened rhetoric, etc.

Tolkien's fantasy has sipped from the sources of epic fantasy and children's fiction. These genres have an enormous semiotic potential, thanks to the fact that they incorporate ancestral myths and signs. These literary forms use symbols that have a universal validity. This is why they have easily survived history. Because of this development of traditional literary forms, we can apply to Tolkien the popular saying according to which mediocre writers imitate, and good ones copy.

The use of popular structures and narrative motifs in Tolkien's fiction contributes to appreciation among its readers, who are familiar with the heroic pattern: the hero embarks on quests, enters a wood full of dangers, receives the help of supernatural auxiliaries, and defeats villains of formidable strength. The chivalric novel has prepared the reader for the ceremonious rituals, the magnificent forms of verbal expression, the moral chivalric code, the anagnórisis, etc. Tolkien's fiction rewards the reader who is familiar with the popular narratives that inspire the structure of its literary fantasy.

3. So, we can read expressions of this kind: "Mourn not overmuch! Mighty was the fallen, meet was his ending. When his mound is raised, women then shall weep. War now calls us!' (III, 145) or "As a father you were to me, for a little while" (III, 314). 


\section{REFERENCES}

Carpenter, H., ed., and C. Tolkien, assistant. 1981. The Letters of J. R.R. Tolkien. London: HarperCollins.

Carpenter, H. 1977. The Inklings. C. S. Lewis, J. R. R. Tolkien, Charles Williams. London: George Allen \& Unwin.

Colomer, T. 1998. La formació del lector literari. Barcelona: Barcanova.

Grotta, D. 1976. The Biography of J. R. R. Tolkien. Philadelphia, Pennsylvania: Running Press.

Kuznets, L. R. 1981. "Tolkien and the Rhetoric of Childhood". Tolkien. New Critical Perspectives. Ed. N. D. Isaacs et al. Lexington, Kentucky: The University Press of Kentucky. 150-162.

Shippey, T. A. 1992. The Road to Middle Earth. London: HarperCollins Publishers.

Tolkien, C., ed. 2002. The History of Middle-earth. Thirteen volumes. New York: Ballantine Books.

Tolkien, J. R. R. 1969 (1954). The Two Towers. New York: Ballantine Books.

—, 1973 (1937). The Hobbit. New York: Ballantine.

-, 1973 (1954). The Return of the King. New York: Ballantine.

-, 1979 (1954). The Fellowship of the Ring. New York: Ballantine.

—, 1979 (1977). The Silmarillion. Ed. C. Tolkien. New York: Ballantine.

—, 1997 (1947). "On Fairy Stories". The Monsters and the Critics and Other Essays. Ed. C. Tolkien. London: HarperCollins. 109-161.

West, R. C. 1975. "The Interlace Structure of The Lord of the Rings". A Tolkien Compass. Ed. J. Lobdell. New York: Ballantine. 82-102. 